\title{
An Early Chellean Palæolithic Workshop-site at Cromer.
}

\begin{abstract}
A $\mathrm{T}$ a meeting of the Royal Anthropological Institute held in the rooms of the Royal Society, Burlington House, on May 3, Mr. Reid Moir exhibited a large collection of ochreous flint implements, cores, and flakes recovered upo a limited area of foreshore exposed at low water at Cromer, Norfolk. These specimens are remarkable not only for their brilliant and arresting ochreous coloration, but also because of the large and massive size of many of the artefacts. Many of them are evidently fashioned for comfortable prehension, but it is clear that the hands of the ancient Cromerian people must have been much larger than those of modern man. Several examples of Early Chellean implements, with coarse flaking upon the upper and lower surfaces, have been found at the Cromer site, associated with rostro-carinates, choppers, scrapers, points, partly finished specimens,
\end{abstract} cores, and flakes.

It is evident that an actual workshop-site of Early Chellean age is represented at Cromer, and from its position appears to be referable to the lowermost stratum of the Cromer Forest Bed series of deposits. The Cromer Forest Bed strata are generally regarded as of Upper Pliocene age, and it seems, therefore, that the earliest Chellean implements-such as are usually found in river-terrace gravels-must in East Anglia be regarded as of Pliocene date. It is of interest to note that the massive human fossil jawbone found at Heidelberg, in Germany, was supposed to be of about the same antiquity as the Cromer Forest Bed. The individual represented by this jawbone would appear to have been of almost gorilla-like size and strength, and it may be that the massive Cromer implements which have been found were made by people of the Heidelberg type.

An animated discussion followed the reading of the paper. Prof. Arthur Keith, past-president, who was in the chair, said that while it wculd be impertinent for him to attempt to criticise Mr. Reid Moir's communication, he considered it of outstanding importance in the study of the antiquity of man in this country. This site would appear to be the most ancient workshop-floor which had yet been discovered.
Sir William Boyd Dawkins said that no geological evidence had been brought forward for the relation of the flints on this site with the Forest Bed series; they were no more than a foreshore accumulation of flints which differed in no way from other flints found on the foreshore along the whole East and South Coast. Further, it was assumed that the Forest Bed fauna was Pliocene; but it had been shown more than forty years ago that the Forest Bed series included recent mammalia absent from the Pliocene deposits of France and Italy, and, therefore, they should be regarded as Early Pleistocene.

Sir E. Ray Lankester said that the use of the terms "Pliocene" and "Pleistocene" was purely arbitrary, and did not affect the facts. These specimens were quite unlike foreshore flints in their large size, their flaking, and their coloration. Mr. S. Hazzledine Warren denied that any evidence had been brought forward in support of the very definite assertion of date, and it was his opinion that if a boring were made at the base of the cliff, as had been suggested, nothing similar to the conditions on the foreshore would be found at the base of the Forest Bed series. Mr. Haward considered the site represented merely an outcrop of one of the zones of flints which are found sloping down to the sea in the neighbouring cliffs. Mr. Barnes said that the case was not made out. The number of implements was small, while a flake afforded little as a criterion of human manufacture. It was essential that a boring should be made at the base of the cliff. Mr. Reginald Smith, on the other hand, maintained that Mr. Reid Moir had made out a prima-facie case; it was only the question of provenance which gave rise to doubt. In referring to the disproportionate number of flakes on the site, he mentioned one of the floors investigated at Swanscombe, on which no implements, but only a large number of flakes, had been found.

The series of humanly fashioned flints collected by Mr. Reid Moir is to remain on exhibit for one month in the rooms of the Royal Society, Burlington House, where the specimens can be seen and examined by those interested.

\section{Hydrology of the Western States of North America. ${ }^{1}$}

\section{By Dr. Brysson Cunningham.}

$\mathrm{T}$ HREE Water Supply Papers, prepared under the direction of the United States Geological Survey, contain features of interest respecting the natural conditions which prevail in the undeveloped territory between the ro8th and I 8 th meridians of west longitude.

(I) A sequence of devastating floods which swept the counties of southern California in January, I9I6, is described in Water Supply Paper No. 426, with records of the precipitation, run-off, and attendant phenomena. The rainfall was heaviest and its effects most disastrous in San Diego County, which for nearly a month after the storm was cut off from communication with the rest of the State. The mean precipitation for the period January $14-30$, in different parts of the county, ranged from 20 in. to 30 in.

1 (1) "Southern California Flnods of January, r gr6." By H. D. MeGlashan and F. C. Ehert. Water Supply Paper No. 42 $\mathrm{h}$. (z) "The Navajo Country." By Herhert F.. Gregory. Water Supply Paper No 380 . (3) "Geology and Water Resources of Big Smoky, Clayton, and Alkali Spring Valleys, Nevada." By Oscar F. Meinzer. Water Supply Paper No. 423. (Washington: Government Printing Office 1917.) No. 269 I, VOL. IO7 7
The normal annual rainfall at San Diego is in the neighbourhood of ro-I5 in. As a result of the down. pour the Lower Otay Dam, forming part of the reser. voir system for the city of San Diego, was swept away and the Sweetwater Reservoir developed serious fractures. Twenty-two lives were lost in the flood from the former reservoir. A huge wall of water, variously described as from $6 \mathrm{ft}$. to $20 \mathrm{ft}$. in height, rushed down the valley, covering the distance from the dam-site to Palm City (about ten miles) in fortyeight minutes, and carrying everything before it. An impressive idea of the devastated area is obtained from the photographs which illustrate the report. There is also a large-scale map of the district.

(2) Upon the borders of the States of Utah, New Mexico, and Arizona lies an area of reservation, known as the Navajo Country, set aside for indigenous Indian tribes. It is a region of which very little hitherto has been known, and it remains more or less in a primitive condition. The area is considerable, about 25,725 square miles; it is the most exten- 
sive tract of undeveloped reservation land within the United States. This area forms the subject of a geographical and hydrographical reconnaissance by $\mathrm{Mr}$. Gregory, whose report is embodied in Water Supply Paper No. 380.

The exploration of a little-known region has considerable attractions for the adventurous; and $\mathrm{Mr}$. Gregory in a personal introductory note confesses to its powerful appeal. The Navajo country, he points out, contains the remnants of an almost extinct race whose long occupation of the district is recorded in ruined dwellings and abandoned fields. It is true that roads have been established along selected routes, but by far the larger portion of the territory is accessible only by trails, and in the rougher areas no recognisable tracks are to be found.

The country contains many extremely interesting features, topographical, geological, and hydrographical. The 200 pages of the report are replete with valuable notes on the natural resources of the district, and indicate a careful and painstaking inves. tigation. Topographically, the country forms part of the Colorado plateau, a region of flat-lying or slightly tilted rocks, cut by cañons and surmounted by mesas and buttes. "So numerous and so closely interlaced are the cañons in some portions of this singular region that they have displaced all but scattered remnants of the original plateau, leaving narrow walls, isolated ridges, and spires so slender that they seem to totter on their bases, shooting up to an enormous height from the vaults below."

The most inaccessible, least known, and roughest portion of the reservation is a region of bare red sandstone rock forming a plateau, known as the Rainbow Plateau, intersected by innumerable cañons, some of which are bridged by natural arches. One of them is a symmetrical semi-circular curve with a span of $274 \mathrm{ft}$. It gives its name of "The Rainbow" to the plateau.

The Navajo Indian is given a fairly good character; he is vigorous, intelligent, and capable of hard work provided it be not too continuous. $\mathrm{He}$ is, however, independent towards those who engage his services, and liable to take himself off. "He will help himself to interesting trinkets and to food, but may be trusted with valuable things and with important missions."

The report is well illustrated by photographs and maps.

(3) Big Smoky Valley, the subject of Water Supply Paper No. 423 , is a typical Nevada desert valley-a plain hemmed in by mountain ranges and underlain by porous rock-waste eroded therefrom. It once contained two large lakes, one 40 miles long and 9 miles in maximum width in the upper part of the valley, and the other about 22 miles long by $5 \frac{1}{2}$ miles wide in the lower part. The depth of the former ranged to as much as $170 \mathrm{ft}$, and of the latter to $70 \mathrm{ft}$. The existence of these lakes is deduced from shore features which are still in existence. The climate is distinctly characteristic of an arid tract, the annual rainfal being generally about 6 in. or 7 in., or even less. The valley is but sparsely populated, and the settlers are principally engaged in mining or milling. The report contains maps, diagrams, and photographs.

\section{The Plaice Fishery in the Belt Sea and Neighbouring Waters. ${ }^{1}$}

THE sea-fisheries of Great Britain, though perhaps of less importance to the prosperity of the country than the supply of coal, are nevertheless of vital interest in more ways than one. Consequently, anything bearing on the problems connected with them, especially as to their permanence, ought to awaken interest in all who have practically studied this intricate subject, as well as to arrest the attention of the legislators and the public. Few nations have done more in proportion to their populations than the Danes in unravelling various problems of the seafisheries, and were it only for the single case of the remarkable life-history of the eel as elucidated by Dr. Johs. Schmidt, their labours merit careful attention as well as commendation.

The Report of the Danish Biological Station for 1920, by the experienced expert Dr. Petersen, who is well known in fisheries researches and for transplanting so successfully the plaice into the Limfjord, discloses a new feature in the plaice-fishery of the Belt Sea and neighbouring waters. No fish in the North Sea, indeed, has given more solicitude to scientific investigators and the fishing industry than the plaice, which, after the twenty years' labours of the International Fisheries Council, was singled out as the only form requiring legislation. Dr. Petersen, the author of the Danish report, hitherto has held the belief that it was possible to produce impoverishment of certain areas by over-fishing, though at the Dundee meeting of the British Association in 1912, when "impoverishment" was challenged, he declined to give an opinion, nor did anyone present support it. Dr. Petersen, indeed, had in former years pointed out l "On the Stock of Plaice in Relation to the Intensive Fishing of the Present Times in the Belt Sea and other Waters." Report of the Danish Biological Station to the Danish Board of Agricult ure, xxvii., rg2o. By Dr. C. G. J. Petersen. (Copenhagen: G. E. C. Gad, rgaz.)

$$
\text { No. } 269 \text { I, VOL. IO7] }
$$

the decline of a Danish plaice-fishery, but, as Dr. H. M. Kyle afterwards proved, that was a misapprehension. Now in this report of 1920 we have the remarkable admission that the intensive plaicefishing, first by gill-nets and then by seines with otterboards (which increased greatly from 1912 to I9I9) worked from motor-boats in the Belt Sea and neighhourhood, has resulted, not in the impoverishment of the area, but in the more rapid growth of the plaice of to-day. The plaice now fished are younger, larger, and better fishes than formerly, though they are fewer on a given hectare, but the yearly yield is larger. Further, in the words of Dr. Petersen, "the plaice got formerly we did not care to eat .. . now we regard them as delicacies."

Dr. Petersen supports his views by the FiskereiBeretnings statistics for twenty years, which show that this intensive fishery has had the effect of increasing the weight of plaice from dn average of $5 \mathrm{~kg}$. per score to ro $\mathrm{kg}$. per score. The original dense old stock has been fished out, and a new, quick-growing race, fewer in number per hectare, has fortunately appeared. "It is like a lawn which is cut many times a year in lieu of once every second year; the latter method produces old, bad grass only, the former gives much more and better grass, but calls for much more work." Instead of 500 tons before I900, the fishery of the area now produces Iooo tons; indeed, in I912, I9I3, and Igrg the yield was about 3000 tons, and valued at 3,000,000 kroner.

In 1900 the fishing in the Great Belt at $22 \mathrm{~m}$. produced many undersized plaice amongst the larger forms of $40 \mathrm{~cm}$., and there was a majority of males. In 1920 there were few undersized forms, and generally they were larger and heavier than before, the larger being similar to the larger in 1900, and 